\title{
Faktor Pendukung dan Penghambat Niat Penggunaan Blockchain oleh Auditor di Kantor Akuntan Publik
}

\author{
Vinsensa M. S. Gero' \\ Fakultas Ekonomi dan Bisnis \\ Universitas Udayana, Indonesia
}

\author{
I Made Sadha Suardikha ${ }^{2}$ \\ Fakultas Ekonomi dan Bisnis \\ Universitas Udayana, Indonesia
}

\begin{abstract}
ABSTRAK
Penelitian ini bertujuan untuk menguji faktor-faktor yang mempengaruhi niat penggunaan Blockchain oleh auditor yang bekerja di KAP di Bali. Pendekatan yang diambil didasarkan pada kombinasi model UTAUT dan SQBT. Ekspektasi Kinerja, Ekspektasi Usaha, Faktor Sosial Budaya dan Kondisi yang Memfasilitasi ditentukan sebagai indikator faktor yang mendukung niat penggunaan Blockchain. Faktor penghambat diadaptasi dari SQBT, yaitu Ketidakpastian, Penghindaran Kerugian, Biaya Tertanam dan Penghindaran Penyesalan. Metode sampling menggunakan teknik purposive sampling. Data penelitian diperoleh melalui metode survei dengan teknik kuesioner. Analisis data penelitian menggunakan regresi linear berganda. Hasil penelitian menunjukkan ekspektasi usaha dan faktor sosial budaya memiliki pengaruh positif terhadap niat penggunaan Blockchain oleh auditor yang bekerja di KAP di Bali. Sementara, hanya biaya tertanam yang ditemukan memiliki pengaruh negatif terhadap niat penggunaan Blockchain oleh auditor.
Kata Kunci: Blockchain; Faktor Pendukung; Faktor Penghambat; Auditor.

Surel : gvinsensa1@gmail.com

\section{Enablers and Inhibitors of Intention to Use Blockchain by Auditors in Audit Firm in Bali}

\section{ABSTRACT}

This study aims to examine the factors that influence the intention to use Blockchain by auditors working at audit firm in Bali. The approach taken is based on a combination of the UTAUT and SQBT models. Performance Expectancy, Effort Expectancy, Socio-Cultural Factors and Facilitating Conditions are determined as enabler factors that support the intention to use Blockchain. The inhibiting factors were adapted from SQBT, namely Uncertainty, Loss Aversion, Sunk Costs and Regret Avoidance. The sampling method uses purposive sampling technique. The research data were obtained through a survey method and analysed using multiple linear regression. The results showed that effort expectancy and socio-cultural factors have positive influence on the intention to use Blockchain by auditors working at audit firm in Bali. Meanwhile, only sunk costs were found to have negative influence on the intention of using Blockchain by auditors.

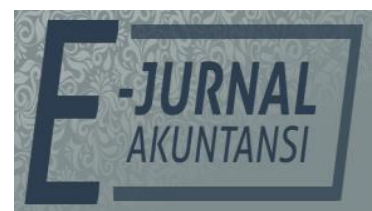

e-ISSN 2302-8556

Vol. 30 No. 10

Denpasar, Oktober 2020

Hal. 2604-2618

DOI:

10.24843/EJA.2020.v30.i10.p13

PENGUTIPAN:

Gero, Vinsensa M. S., \&

Suardikha, I.M.S. (2020).

Faktor Pendukung dan

Penghambat Niat

Penggunaan Blockchain oleh

Auditor di Kantor Akuntan

Publik. E-Jurnal Akuntansi, 30(10), 2604-2618

RIWAYAT ARTIKEL:

Artikel Masuk:

6 Juli 2020

Artikel Diterima:

5 Oktober 2020

Keywords: Blockchain; Enabler; Inhibitor; Auditor.

Artikel dapat diakses : https://ojs.unud.ac.id/index.php/Akuntansi/index 


\section{PENDAHULUAN}

Dewasa ini perkembangan teknologi melaju dengan pesat dan pemanfaatannya sudah melebur dalam kehidupan manusia (Ngafifi, 2014). Sepanjang dua setengah abad ini tatanan industri terus berkembang seiring dengan kemajuan teknologi. Revolusi digital yang telah terjadi sejak pertengahan abad yang lalu. Hal ini ditandai dengan perpaduan teknologi yang mengaburkan garis antara bidang fisik, digital, dan biologis (Schwab, 2016). Internet of Things (IoT), Big Data, Artificial Intelligence, Blockchain, 3D Printing, Sharing Economy dan biotechnology termasuk dalam kategori utama yang akan mempengaruhi hidup kita secara signifikan pada era revolusi industri keempat (Chung \& Kim, 2016).

Di antara berbagai teknologi mutakhir yang telah disebutkan, Blockchain dinilai sebagai teknologi baru yang paling berpotensi dalam mentransformasi audit (Psaila, 2017). Kemunculan suatu teknologi baru, apalagi yang sifatnya disruptif, patut diteliti berkaitan dengan pihak-pihak yang berpotensi menggunakannya. Salah satu teori yang sering digunakan untuk mengetahui niat penggunaan dan perilaku penggunaan teknologi adalah Unified Theory of Acceptance and Use of Technology (UTAUT). Teori ini dikembangkan oleh Venkatesh, Morris, Davis, \& Davis (2003) dengan menjabarkan empat konstruk yang berperan secara langsung dalam penentuan penerimaan pengguna dan perilaku penggunaan teknologi, yaitu ekspektasi kinerja, ekspektasi usaha, faktor sosial dan kondisi yang memfasilitasi. Niat berperilaku (behavioral intention) mengacu pada probabilitas subyektif seseorang bahwa ia akan melakukan suatu kegiatan/perilaku. Ariyanto, Sari, \& Ratnadi (2017) memodifikasi model UTAUT dengan menggunakan variabel baru yang telah divalidasi, yaitu Faktor Sosial Budaya (FSB) dalam konteks kearifan lokal Bali, yaitu Budaya Tri Hita Kirana (THK) untuk menggantikan variabel faktor sosial.

Meskipun banyak inisiatif yang dilakukan untuk meningkatkan penggunaan teknologi, namun penggunaan teknologi audit oleh auditor dapat dikatakan masih rendah dan belum mencapai kemajuan yang memadai (Veerankutty, Ramayah, \& Ali, 2018). Bukti historis telah menunjukkan bahwa auditor cenderung lambat dalam mengadopsi teknologi, dan baru akan melakukannya jika keadaan memaksa (Alles, 2015). Keengganan untuk mengadopsi teknologi atau keinginan untuk mempertahankan keadaan yang sama disebut sebagai bias status quo. Teori yang digunakan untuk menjelaskan preferensi atau alasan seorang individu untuk mempertahankan status atau situasi yang ada saat ini (status quo) ialah Teori Bias Status Quo (SQBT) yang dikembangkan oleh Samuelson \& Zeckhauser (1988). Penyebab individu mempertahankan keadaan yang sama adalah karena adanya ketidakpastian, penghindaran kerugian, biaya tertanam, dan penghindaran penyesalan (Samuelson \& Zeckhauser, 1988).

Menurut Koens \& Poll (2019), blockchain adalah database terdistribusi yang berisi catatan yang dibagikan di antara anggota yang berpartisipasi, yaitu pengguna dan penambang. Pengguna dapat Pengguna dapat melakukan transaksi kapan saja dan transaksi tersebut kemudian disiarkan dalam jaringan peer-to-peer yang di dalamnya terkandung alamat publik penerima, nominal transaksi, tanda tangan digital pengirim dan alamat publik pengirim untuk diverifikasi oleh penambang. Kemudian, transaksi yang sudah dipastikan 
keabsahannya, akan digabungkan dengan transaksi-transaksi lainnya dan dimasukkan dalam blok-blok terenskripsi. Blok baru kemudian ditautkan dengan blok-blok yang sudah ada dalam jaringan. Karena pengidentifikasi unik (hash) dari blok sebelumnya termasuk dalam blok yang baru, maka setiap blok akan tersambung dan membentuk rantai blok (blockchain).

Blockchain merupakan salah satu teknologi yang termasuk dalam Computer-Assisted Audit Tools and Techniques (CAATT) yang digunakan untuk menyelesaikan pekerjaan audit (Abreu, Aparicio, \& Costa, 2018). Menurut Psaila (2017), blockchain dapat dianggap sebagai buku besar yang didistribusikan yang berisi rincian yang relevan untuk setiap transaksi yang pernah diproses. Karena sifatnya inilah yang memungkinkan auditor untuk memperoleh informasi lebih cepat dan melaksanakan audit secara real-time. Oleh sebab itu, auditor perlu mempersiapkan diri dalam menghadapi tantangan dan peluang yang muncul bersamaan dengan kemajuan teknologi. Appelbaum \& Nehmer (2017) menjabarkan perbedaan antara prosedur audit dalam metode "tradisional" dan prosedur audit dalam penerapan blockchain serta peluang dan tantangannya (Chedrawi \& Howayeck, 2018) sebagai berikut.

Tabel 1. Perbandingan Prosedur Audit: Prosedur Manual Tradisional dan Prosedur Berkelanjutan yang Didukung Blockchain

\begin{tabular}{|c|c|c|}
\hline Prosedur & Metode "Tradisional" & Blockchain \\
\hline $\begin{array}{l}\text { Pemeriksaan atau } \\
\text { Inspeksi Catatan } \\
\text { atau Dokumen }\end{array}$ & $\begin{array}{l}\text { Mengambil sampel dari catatan } \\
\text { dan lacak / verifikasi / cocokkan. }\end{array}$ & $\begin{array}{l}\text { Memungkinkan evaluasi seluruh } \\
\text { data dalam sistem. }\end{array}$ \\
\hline Pemeriksaan Aset & Inventaris fisik, memeriksa secara & Penandaan dengan RFID (RFID \\
\hline Berwujud & langsung (walk through; open boxes) & tagging) \\
\hline Pengamatan & $\begin{array}{l}\text { Melihat apakah para pekerja } \\
\text { melaksanakan tugas yang } \\
\text { diberikan sesuai dengan kebijakan } \\
\text { dan prosedur perusahaan. }\end{array}$ & $\begin{array}{c}\text { Gunakan blockchain atau proses } \\
\text { penambangan untuk } \\
\text { memverifikasi alur kerja. }\end{array}$ \\
\hline Penyelidikan & $\begin{array}{l}\text { Permintaan keterangan secara } \\
\text { lisan atau tertulis. }\end{array}$ & $\begin{array}{l}\text { Memonitor proses dan } \\
\text { pengendalian, mengidentifikasi } \\
\text { pelanggar proses untuk diuji. }\end{array}$ \\
\hline Konfirmasi & Verifikasi saldo akun. & $\begin{array}{l}\text { Menautkan peralihan data } \\
\text { menggunakan aplikasi blockchain. }\end{array}$ \\
\hline $\begin{array}{l}\text { Penghitungan } \\
\text { Ulang }\end{array}$ & $\begin{array}{l}\text { Verifikasi dengan mengekstrak } \\
\text { dan menghitung ulang jumlah } \\
\text { yang tertera dalam catatan. }\end{array}$ & $\begin{array}{l}\text { Pantau semua data dan jalankan } \\
\text { perhitungan secara otomatis pada } \\
\text { interval yang diinginkan. }\end{array}$ \\
\hline Pelaksanaan Ulang & $\begin{array}{l}\text { Melaksanakan ulang prosedur } \\
\text { untuk memverifikasi. }\end{array}$ & $\begin{array}{l}\text { Secara otomatis mereplikasi semua } \\
\text { transaksi dan mengidentifikasi } \\
\text { transaksi yang dikecualikan. }\end{array}$ \\
\hline Prosedur Analitis & $\begin{array}{l}\text { Memindai dan penggunaan model } \\
\text { matematis dan statistik. }\end{array}$ & $\begin{array}{c}\text { Memfilter data secara real-time } \\
\text { dengan persamaan kontinuitas } \\
\text { dan statistik. }\end{array}$ \\
\hline
\end{tabular}

Sumber: Appelbaum \& Nehmer, 2017 


\section{Tabel 2. Peluang dan Tantangan Blockchain Bagi Audit}

\begin{tabular}{|c|}
\hline Peluang Blockchain \\
\hline $\begin{array}{l}\text { Data yang tersimpan tidak dapat } \\
\text { dimodifikasi. }\end{array}$ \\
\hline $\begin{array}{l}\text { Transakasi yang direkam dapat di } \\
\text { transparan kepada kedua pihak } \\
\text { bertransaksi. }\end{array}$ \\
\hline
\end{tabular}

$\begin{array}{ll}\text { Tantangan Blockhain } \\ \text { Penipuan tidak dapat dihindari } \\ \text { sepenuhhnya } & \text { meskipunblockchain } \\ \text { menjanjikan transaksi yang sangat aman. }\end{array}$

Jika karyawan entitas secara tidak sengaja atau sengaja mengirimkan uang virtual (bitcoin) ke alamat penerima yang tidak benar atau tidak sah, saat ini tidak ada cara untuk membatalkan transaksi itu.

Transaksi yang dilakukan dapat Jika suatu entitas mengalami serangan diverifikasi melalui blockchain. phishing, tidak ada fraud department untuk menangani kasus tersebut karena blockchain tidak memiliki administrasi pusat. Situasi ini juga dapat berkontribusi dalam risiko penipuan.

Otomatisasi dalam proses verifikasi dapat mendorong efisiensi biaya audit.

Jika kunci pribadi hilang (mis. terjadi kerusakan perangkat lunak atau perangkat keras) entitas kehilangan akses ke mata uang virtual apa pun (seperti bitcoin) yang dikaitkan dengan kunci pribadi ini. Prosedur pemulihan yang efektif serta prosedur cadangan dan restorasi dapat membantu pencegahan situasi tersebut.

Blockchain memampukan auditor untuk menguji seluruh populasi transaksi dalam periode yang diaudit. Dengan kata lain, pengujian substantif tidak dilaksanakan pada sampel, sehingga terjadi peningkatan yang luar biasa dalam kualitas audit.

Karakteristik blockchain juga secara positif mempengaruhi proses audit yang mengarah kepada penilaian berkelanjutan Blockchain merupakan produk buatan manusia, dengan kata lain perangkat lunak dan antarmuka akan dibuat oleh coders yang bisa salah dan rusak. via daring selama periode audit.

Sumber : Chedrawi \& Howayeck, 2018

Penelitian ini bertujuan untuk mengetahui apa sajakah faktor-faktor pendukung dasn penghambat niat penggunaan blockchain oleh auditor di KAP di Bali. Faktor-faktor pendukung tersebut ialah, ekspektasi kinerja, ekspektasi usaha, faktor sosial budaya dan kondisi yang memfasilitasi. Faktor-faktor penghambat ialah ketidakpastian, penghindaran kerugian, biaya tertanam dan penghindaran penyesalan.

Ekspektasi kinerja didefinisikan sebagai sejauh mana seorang individu percaya bahwa dengan menggunakan sistem maka ia untuk mendapat keuntungan, yaitu berupa peningkatkan kinerja (Venkatesh et al., 2003). Blockchain menawarkan otomatisasi bagi auditor. Audit yang memanfaatkan blockchain akan meningkatkan efisiensi, efektivitas, dan keandalan proses pengumpulan bukti audit (Appelbaum \& Smith, 2018). Artinya dengan menggunakan blockchain, kinerja auditor berpotensi untuk mengalami 
peningkatan dan mencapai hasil yang diharapkan. Apabila individu merasa pekerjaannya dimudahkan karena menggunakan suatu teknologi, akan berminat untuk memanfaatkan teknologi tersebut dan menggunakannya secara berkelanjutan (Jayanti \& Ariyanto, 2018). Argumen ini sesuai dengan UTAUT yang menyatakan bahwa konstruk ekspektasi kinerja merupakan prediktor terkuat dan signifikan terhadap niat penggunaan teknologi. Penelitian yang dilakukan oleh Dian Saputra \& Dwirandra (2015) dan Dewi Mas Yogi Pertiwi \& Ariyanto (2017) menyimpulkan bahwa terdapat pengaruh positif dari ekspektasi kinerja terhadap niat penggunaan blockchain. Berdasarkan uraian di atas, maka hipotesis penelitian dapat dirumuskan sebagai berikut.

$\mathrm{H}_{1}$ : Ekspektasi Kinerja berpengaruh positif terhadap Niat Penggunaan Blockchain.

Ekspektasi usaha didefinisikan sebagai tingkat kemudahan dalam penggunaan teknologi (Venkatesh et al., 2003). Apabila blockchain dipersepsikan mudah untuk dioperasikan, maka niat penggunaannya pun akan meningkat. Argumen ini sesuai dengan UTAUT yang menyatakan bahwa ekspektasi usaha merupakan faktor penentu terkuat atas niat penggunaan teknologi oleh individu yang minim pengalaman dalam pengoperasian teknologi. Penelitian yang dilakukan oleh Dian Saputra \& Dwirandra (2015), Heryangi \& Ariyanto (2018) dan Komala Dewi \& Yadnyana (2017) menyimpulkan bahwa terdapat pengaruh positif dari ekspektasi usaha terhadap niat penggunaan blockchain. Berdasarkan uraian di atas, maka hipotesis penelitian dapat dirumuskan sebagai berikut.

$\mathrm{H}_{2}$ : Ekspektasi Usaha berpengaruh positif terhadap Niat Penggunaan Blockchain.

Ariyanto, et al (2017), mendefinisikan Faktor Sosial Budaya sebagai persepsi individu terkait penggunaan teknologi dipengaruhi oleh orang-orang yang dianggap penting olehnya, pendapat atau pemikirannya sendiri dan tingkat spiritualitasnya. Individu, dalam hal ini auditor, akan berniat menggunakan teknologi mutakhir (blockchain) apabila rekan kerja dan pemimpin, juga pendapat pribadi dan tingkat spiritualistasnya mendukung penggunakan teknologi tersebut. Argumen ini sesuai dengan UTAUT yang menjelaskan bahwa individu cenderung mendengarkan pendapat orang lain atau peduli terntang bagaimana pandangan orang lain terhadap diri mereka, sehingga variabel ini memiliki pengaruh besar dalam terbentuknya niat penggunaan teknologi baru. Penelitian yang dilakukan oleh Jayanti \& Ariyanto (2018) dan Ariyanto, et al., (2017) menyimpulkan bahwa terdapat pengaruh positif dari faktor sosial budaya terhadap niat penggunaan blockchain. Berdasarkan uraian di atas, maka hipotesis penelitian dapat dirumuskan sebagai berikut.

$\mathrm{H}_{3}$ : Faktor Sosial Budaya berpengaruh positif pada Niat Penggunaan Blockchain.

Kondisi yang memfasilitasi didefinisikan sebagai sejauh mana seorang individu percaya bahwa infrastruktur organisasi dan teknis ada untuk mendukung penggunaan sistem (Bierstaker, Janvrin, \& Lowe, 2014). Bierstaker et al. (2014) menyatakan bahwa kondisi yang memfasilitasi melibatkan infrastruktur yang diperlukan, seperti sumber daya teknologi audit dan dukungan komputer yang sesuai untuk auditor mereka, seperti instruksi khusus, pusat dukungan (support center), hotline, dan/atau pedoman penggunaan. Semakin banyak fasilitas, baik infrastruktur maupun sarana dan prasarana teknis lainnya yang disediakan oleh organisasi guna mendukung penggunaan teknologi, maka niat seseorang untuk memanfaatkannya akan semakin 
meningkat (Venkatesh et al., 2003). Auditor perlu untuk mempelajari cara pengggunaan blockchain, maka tersedianya infrastruktur yang memadai akan mendorong auditor untuk menggunakan teknologi tersebut. Penelitian yang dilakukan oleh Hsieh (2016) dan Mosunmola et al. (2018) menyimpulkan bahwa terdapat pengaruh positif dari kondisi yang memfasilitasi terhadap niat penggunaan blockchain. Berdasarkan uraian di atas, maka hipotesis penelitian dapat dirumuskan sebagai berikut.

$\mathrm{H}_{4}$ : Kondisi yang memfasilitasi berpengaruh positif pada Niat Penggunaan Blockchain.

Suhendro, Siregar, \& Nauli (2015) menyatakan bahwa ketidakpastian merupakan persepsi mengenai risiko terkait penerapan teknologi baru, karena terbatasnya informasi dan belum memiliki pengalaman langsung dalam mengoperasikan teknologi tersebut. H.-W. Kim (2011) Jika individu memiliki pengetahuan yang terbatas tentang teknologi baru dan perubahan yang akan terjadi terkait implementasinya, maka individu tersebut akan merasa gamang terkait tugas mereka dan kinerja teknologi tersebut sehingga niat penggunaannya pun akan menurun. Argumen ini sesuai dengan SQBT yang menjelaskan bahwa jika individu memiliki pengetahuan yang terbatas tentang suatu pilihan alternatif, maka individu mungkin tidak akan beralih ke pilihan alternatif dan tetap mempertahankan status quo. Ketidakpastian diidentifikasi sebagai salah satu faktor penghambat dalam pengadopsian suatu teknologi (ReyMoreno \& Medina-Molina, 2017) dan (K. Lee \& Joshi, 2016). Berdasarkan uraian di atas, maka hipotesis penelitian dapat dirumuskan sebagai berikut.

$\mathrm{H}_{5}$ : Ketidakpastian berpengaruh negatif pada Niat Penggunaan Blockchain.

Penghindaran kerugian merupakan kecenderungan individu untuk lebih mempertimbangkan kerugian daripada keuntungan karena adanya keinginan untuk menghindari kerugian tersebut (K. Lee \& Joshi, 2016). Auditor perlu mempertimbangkan potensi kerugian yang akan dialami sebelum memutuskan untuk mengadopsi teknologi baru. Karena adanya perbedaan antara teknologi yang digunakan saat ini dengan teknologi audit yang baru, menggantikan teknologi yang digunakan saat ini kemungkinan akan menjadi semakin sulit dan mahal bagi auditor. Ketidakmampuan untuk bekerja akibat pergantian teknologi dipandang lebih penting daripada manfaat yang diterima dari teknologi baru yang akan diimplementasi, yang kemudian menyebabkan resistensi penggunaan (K. Lee \& Joshi, 2016). Argumen ini sesuai dengan SQBT yang menjelaskan bahwa jika individu merasa potensi kerugian akan lebih besar dibandingkan potensi manfaat dari suatu pilihan alternatif, maka ia akan cenderung menolak perubahan tersebut dan bertahan pada status quo. Penghindaran Kerugian diidentifikasi sebagai salah satu faktor penghambat dalam pengadopsian suatu teknologi (Rey-Moreno \& Medina-Molina, 2017) dan (K. Lee \& Joshi, 2016). Berdasarkan uraian tersebut maka hipotesis yang dapat dikembangkan adalah sebagai berikut.

$\mathrm{H}_{6}$ : Penghindaran Kerugian berpengaruh negatif pada Niat Penggunaan Blockchain.

Biaya tertanam didefinisikan sebagai kecenderungan individu untuk membenarkan komitmennya dalam melakukan sesuatu dengan terus mempertahankan komitmennya itu (Rey-Moreno \& Medina-Molina, 2017). 
Semakin besar investasi auditor dalam upaya mempelajari, pengalamannya dan keahliannya dalam menggunakan teknologi yang ada saat ini, semakin tinggi kecenderungannya untuk bertahan pada status quo. Argumen ini sesuai dengan SQBT yang menjelaskan bahwa semakin besar investasi di masa lalu dalam suatu keputusan atau perilaku, semakin besar kecenderungan individu untuk komit atau mewajibkan diri dalam menjalankan keputusan dan perilakunya (Samuelson \& Zeckhauser, 1988). Biaya tertanam diidentifikasi sebagai salah satu faktor penghambat dalam pengadopsian suatu teknologi (Rey-Moreno \& Medina-Molina, 2017) dan (K. Lee \& Joshi, 2016). Berdasarkan uraian yang telah disebutkan, maka hipotesis yang dirumuskan adalah sebagai berikut.

$\mathrm{H}_{7}$ : Biaya Tertanam berpengaruh negatif pada Niat Penggunaan Blockchain.

Penghindaran penyesalan merupakan kecenderungan individu untuk menyesali keputusannya beralih menggunakan teknologi baru apabila berakibat buruk daripada dampak serupa yang terjadi karena mempertahankan status quo (Hsieh, 2016). Hal ini terjadi karena individu menyesali konsekuensi negatif dari keputusan mereka untuk melakukan sesuatu yang baru dibandingkan dengan konsekuensi negatif yang terjadi karena tidak melakukan hal tersebut (Samuelson \& Zeckhauser, 1988). Auditor akan merasa lebih menyesal apabila ia beranggapan akan memperoleh hasil atau konsekuensi negatif ketika memutuskan untuk menggunakan blockchain, dibandingkan dengan konsekuensi negatif yang dialami karena memutuskan untuk tidak menggunakan teknologi tersebut sama sekali. Argumen ini sesuai dengan SQBT yang menjelaskan bahwa penghindaran penyesalan merupakan komitmen psikologis, yang menyebabkan individu cenderung menghindari pengambilan keputusan yang akan membuat mereka menyesal di kemudian hari, dan mempertimbangkan norma-norma sosial sebagai faktor yang memengaruhi penghindaran penyesalan, dalam hal potensi kerugian, yang kemudian berujung pada bias terhadap status quo. Penghindaran penyesalan diidentifikasi sebagai salah satu faktor penghambat dalam pengadopsian suatu teknologi (Rey-Moreno \& Medina-Molina, 2017) dan (K. Lee \& Joshi, 2016). Berdasarkan uraian yang telah dipaparkan, hipotesis yang dirumuskan adalah sebagai berikut.

$\mathrm{H}_{8}$ : Penghindaran Penyesalan berpengaruh negatif pada Niat Penggunaan Blockchain.

\section{METODE PENELITIAN}

Penelitian dilaksanakan di Kantor Akuntan Publik di Provinsi Bali yang tercatat dalam Direktori yang dirilis oleh Institut Akuntan Publik Indonesia (IAPI) pada tahun 2019. Data diperoleh dengan metode survey dengan menggunakan kuesioner mengenai variabel yang diteliti dalam penelitian ini. Populasi penelitan merupakan auditor yang bekerja di KAP di Bali yang berjumlah 65 orang. Metode purposive sampling digunakan sebagai metode penentuan sampel dalam penelitian ini, dengan demikian jumlah sampel penelitian adalah 56 orang. Obyek penelitian ini adalah niat penggunaan blockchain oleh auditor di KAP di Bali yang dijelaskan oleh faktor pendukung yang terdiri dari ekspektasi kinerja, ekspektasi usaha, faktor sosial budaya dan kondisi yang memfasilitasi, dan faktor penghambat yang terdiri dari ketidakpastian, penghindaran kerugian, biaya tertanam dan penghindaran penyesalan. 
Ekspektasi kinerja diukur dengan indikator: 1) Kebermanfaatan teknologi; 2) Peningkatan kualitas hasil pekerjaan; 3) Efisiensi menyelesaikan satu pekerjaan. Ekspektasi usaha diukur dengan indikator kemudahan dalam: 1) Mempelajari penggunaan teknologi; 2) Menjadi mahir atau terampil dalam pengoperasian teknologi; 3) Penggunaan teknologi secara keseluruhan. Faktor sosial budaya diukur dengan indikator: 1) Keyakinan bahwa kelancaran dalam menyelesaikan pekerjaan terjadi karena keikhlasan dan doa pribadi; 2) Adanya perasaan bersalah jika melakukan kecurangan dalam pekerjaan; 3) Keyakinan atas hukum Karma Phala; 4) Keyakinan bahwa penggunaan teknologi dapat mendukung kelangsungan usaha; 5) Keyakinan bahwa penggunaan teknologi mendukung efisiensi dan efektivitas dalam pekerjaan; 6) Perhatian pemimpin atas perkembangan teknologi yang berkaitan dengan pekerjaan; 7) Dukungan penggunaan teknologi oleh rekan kerja; 8) Keyakinan bahwa pembelajaran dan penggunaan teknologi mutakhir sebagai langkah antisipatif atas perkembangan teknologi yang dinamis. Kondisi yang memfasilitasi diukur dengan indikator: 1) Tersedianya sumber daya, peluang dan pengetahuan yang dibutuhkan untuk menggunakan teknologi mutakhir; 2) Kompatibilitas teknologi mutakhir dengan pekerjaan; 3) Kesesuaian gaya kerja (work style) dengan teknologi mutakhir.

Ketidakpastian diukur menggunakan indikator: 1) Ketidakpercayaan atas pengaruh teknologi mutakhir terhadap kinerja; 2) Kesulitan pengukuran potensi peningkatan kinerja; 3) Antisipasi terjadinya hal tidak terduga akibat implementasi teknologi mutakhir. Penghindaran kerugian diukur menggunakan indikator kecenderungan terhadap: 1) Biaya moneter; 2) Biaya waktu; 3) Biaya upaya dibandingkan manfaat teknologi mutakhir. Biaya tertanam diukur menggunakan indikator pengorbanan waktu dan biaya untuk: 1) Mempelajari teknologi yang digunakan saat ini; 2) Menjadi mahir atau terampil dalam mengoperasikan teknologi yang digunakan saat ini. Penghindaran penyesalan diukur menggunakan indikator berupa keengganan untuk beralih karena: 1) Alasan emosional; 2) Alasan familiaritas; 3) Tidak ingin menyesal. Niat penggunaan diukur menggunakan indikator: 1) Adanya niat penggunaan teknologi mutakhir jika diberikan akses penggunaannya; 2) Ekspektasi dalam penggunaan teknologi mutakhir pada waktu dekat; 3) Rencana menggunakan teknologi mutakhir dalam waktu dekat. Seluruh variabel diukur dengan skala likert 5, skala 1 berarti Sangat Tidak Setuju (STS) dan skala 5 berarti Sangat Setuju (SS).

Analisis regresi linear berganda digunakan untuk menganalisis data dalam penelitian ini. Model persamaan analisis regresi linear berganda adalah sebagai berikut:

$$
Y=\alpha+\beta_{1} X_{1}+\beta_{2} X_{2}+\beta_{3} X_{3}+\beta_{4} X_{4}+\beta_{5} X_{5}+\beta_{6} X_{6}+\beta_{7} X_{7}+\beta_{8} X_{8}+\varepsilon
$$

Keterangan :

Y : Niat Penggunaan Blockchain

a $\quad$ : Konstanta

$\beta \quad$ : Koefisien Regresi

$\mathrm{X}_{1} \quad$ : Ekspektasi Kinerja

$\mathrm{X}_{2} \quad$ : Ekspektasi Usaha

$\mathrm{X}_{3} \quad$ : Faktor Sosial Budaya

$\mathrm{X}_{4} \quad$ : Kondisi yang Memfasilitasi 
$\mathrm{X}_{5} \quad$ : Ketidakpastian

$\mathrm{X}_{6} \quad$ : Penghindaran Kerugian

$\mathrm{X}_{7} \quad$ : Biaya Tertanam

$\mathrm{X}_{8} \quad$ : Penghindaran Penyesalan

$\varepsilon \quad:$ Kesalahan pengganggu (standard error)

Model regresi yang baik adalah yang telah lolos uji asumsi klasik, yaitu uji normalitas, uji multikolinearitas dan uji heteroskedastisitas. Uji t digunakan untuk mengetahui pengaruh variabel secara parsial, sedangkan uji $\mathrm{F}$ digunakan untuk mengetahui pengaruh variabel secara simultan dan uji Adjusted $\mathrm{R}^{2}$ digunakan untuk mengetahui variasi variabel.

\section{HASIL DAN PEMBAHASAN}

Analisis regresi berganda digunakan untuk menguji pengaruh antara variabel bebas terhadap variabel terikat, yaitu ekspektasi kinerja, ekspektasi usaha, faktor sosial budaya, kondisi yang memfasilitasi, ketidakpastian, penghindaran kerugian, biaya tertanam dan penghindaran penyesalan terhadap niat penggunaan blockchain.

\section{Tabel 3. Hasil Regresi Linear Berganda}

\begin{tabular}{|c|c|c|c|c|c|}
\hline \multirow[t]{2}{*}{ Model } & \multicolumn{2}{|c|}{ Unstandardized Coefficients } & \multirow{2}{*}{$\begin{array}{c}\begin{array}{c}\text { Standardized } \\
\text { Coefficients }\end{array} \\
\text { Beta }\end{array}$} & \multirow[t]{2}{*}{$\mathrm{t}$} & \multirow[t]{2}{*}{ Sig. } \\
\hline & B & Std. Error & & & \\
\hline (Constant) & 6,865 & 2,574 & & 2,667 & 0,010 \\
\hline Ekspektasi Kinerja & $-0,013$ & 0,067 & $-0,018$ & $-0,187$ & 0,853 \\
\hline Ekspektasi Usaha & 0,131 & 0,064 & 0,189 & 2,034 & 0,048 \\
\hline Faktor Sosial Budaya & 0,322 & 0,094 & 0,478 & 3,440 & 0,001 \\
\hline Kondisi yang & $-0,272$ & 0,247 & $-0,148$ & $-1,100$ & 0,277 \\
\hline \multicolumn{6}{|l|}{ Memfasilitasi } \\
\hline Ketidakpastian & $-0,021$ & 0,108 & $-0,029$ & $-0,193$ & 0,848 \\
\hline Penghindaran & $-0,049$ & 0,082 & $-0,064$ & $-0,591$ & 0,557 \\
\hline \multicolumn{6}{|l|}{ Kerugian } \\
\hline Biaya Tertanam & $-0,346$ & 0,104 & $-0,362$ & $-3,334$ & 0,002 \\
\hline Penghindaran & $-0,169$ & 0,118 & $-0,234$ & $-1,436$ & 0,158 \\
\hline \multicolumn{6}{|l|}{ Penyesalan } \\
\hline Adjusted $\mathrm{R}^{2}$ & 0,628 & & & & \\
\hline Sig. F & 0,000 & & & & \\
\hline
\end{tabular}

Sumber: Data Penelitian, 2020

Berdasarkan hasil pengujian regresi linear berganda pada Tabel 4, maka model persamaan regresi linear berganda dalam penelitian ini dapat disusun sebagai berikut.

$Y=6,865-0,013 X_{1}+0,131 X_{2}+0,322 X_{3}-0,272 X_{4}-0,021 X_{5}-0,049 X_{6}-0,346 X_{7}-0,169 X_{8}$

Nilai adjusted $\mathrm{R}^{2}$ sebesar 0,628. Hal ini berarti bahwa $62,80 \%$ dari total variasi niat penggunaan Blockchain oleh auditor di KAP di Bali dapat dijelaskan oleh Ekspektasi Kinerja, Ekspektasi Usaha, Faktor Sosial Budaya, Kondisi yang Memfasilitasi, Ketidakpastian, Penghindaran Kerugian, Biaya Tertanam, Penghindaran Penyesalan dan 37,20\% sisanya dipengaruhi atau dijelaskan oleh faktor-faktor lain yang tidak diuji dalam penelitian ini.

Nilai signifikan $\mathrm{F}$ adalah 0,000 yang bernilai lebih kecil dari nilai $a=0,05$, sehingga dapat dinyatakan bahwa model regresi yang digunakan dalam 
penelitian ini adalah layak. Artinya, variabel Ekspektasi Kinerja, Ekspektasi Usaha, Faktor Sosial Budaya, Kondisi yang Memfasilitasi, Ketidakpastian, Penghindaran Kerugian, Biaya Tertanam dan Penghindaran Penyesalan mampu memprediksi atau menjelaskan variabel Niat Penggunaan Blockchain.

Hasil pengujian hipotesis menunjukkan bahwa variabel Ekspektasi Kinerja $(B=-0,013$;Sig. $=0,853)$ tidak berpengaruh positif terhadap Niat Penggunaan Blockchain, artinya $\mathrm{H}_{1}$ ditolak. Hal ini berarti auditor tidak begitu meyakini bahwa dengan beralih menggunakan Blockchain maka kinerja mereka akan mengalami peningkatan, oleh karena itu pengaruh antara Ekspektasi Kinerja pada Niat Penggunaan Blockchain tidak signifikan. Alasan lainnya ialah karena auditor sudah terbiasa menggunakan teknologi audit yang ada dan tidak begitu mementingkan potensi peningkatan kinerja yang dapat dicapai apabila mereka beralih menggunakan Blockchain. Temuan ini sejalan dengan penemuan Mardiana et al. (2018), Risma Dwinda Putri \& Suardikha (2020) dan Yoo et al. (2012) yang menyatakan bahwa Ekspektasi Kinerja tidak berpengaruh terhadap Niat Penggunaan.

Ekspektasi Usaha $(B=0,131$;Sig. $=0,048)$ berpengaruh positif terhadap Niat Penggunaan Blockchain, artinya $\mathrm{H}_{2}$ diterima. Auditor yakin bahwa bila mereka sering mengoperasikan teknologi Blockchain untuk menyelesaikan pekerjaan mereka, maka mereka akan menjadi mahir. Semakin besar harapan auditor akan kemudahan menggunakan Blockchain dalam menyelesaikan pekerjaannya, akan semakin kuat pula Niat Penggunaannya. Temuan ini sejalan dengan hasil penelitian Dian Saputra \& Dwirandra (2015), Lafraxo et al. (2018), Mosunmola et al. (2018) dan Sedana \& Wijaya (2012).

Faktor Sosial Budaya $(B=0,322 ;$ Sig. $=0,001)$ memiliki pengaruh positif terhadap Niat Penggunaan Blockchain, artinya $\mathrm{H}_{3}$ diterima. Auditor akan mempertimbangkan untuk menggunakan teknologi Blockchain apabila orangorang penting di sekitarnya (rekan kerja, senior, manager, atau pemimpin), pendapat pribadinya dan tingkat spiritualitasnya mendukung pengadopsian teknologi tersebut. Penerapan teknologi baru, dalam hal ini Blockchain, dalam suatu organisasi perlu memperhatikan setiap komponen dalam organisasi, yaitu tugas, struktur, individu, dan budaya yang ada dalam organisasi tersebut. Hasil penelitian Ariyanto et al. (2017) dan Jayanti \& Ariyanto (2018) membuktikan adanya pengaruh dari Faktor Sosial Budaya terhadap Niat Penggunaan teknologi.

Kondisi yang Memfasilitasi $(B=-0,272 ;$ Sig. $=0,277)$ tidak berpengaruh positif terhadap Niat Penggunaan Blockchain, jadi $\mathrm{H}_{4}$ ditolak. Temuan ini sejalan dengan penelitian Zuiderwick (2015) yang menunjukkan bahwa kondisi yang memfasilitasi bukanlah prediktor terbaik untuk niat penggunaan. Menurut Venkatesh et al. (2003), dengan adanya konstruk ekspektasi usaha, konstruk kondisi yang memfasilitasi menjadi tidak signifikan dalam memprediksi niat penggunaan. Dalam konteks organisasi, banyak aspek dalam konstruk kondisi yang memfasilitasi, seperti pelatihan dan fasilitas pendukung, akan disediakan oleh organisasi tersebut bagi seluruh pengguna (karyawan). Dengan demikian, apabila fasilitas-fasilitas yang diperlukan tidak memadai, maka niat penggunaan teknologi pun cenderung rendah. Temuan ini sejalan dengan hasil penelitian Lafraxo et al. (2018), Yoo et al. (2012) dan Zuiderwick (2015) yang tidak 
menemukan pengaruh Kondisi yang Memfasilitasi terhadap Niat Penggunaan teknologi.

Ketidakpastian $(B=-0,021 ;$ Sig. $=0,848)$ tidak berpengaruh terhadap Niat Penggunaan Blockchain, jadi $\mathrm{H}_{5}$ ditolak. Auditor merasa potensi peningkatan kinerja masih belum dapat dipastikan karena auditor belum pernah mengoperasikan Blockchain untuk menyelesaikan pekerjaannya untuk dapat dibandingkan dengan teknologi audit yang sudah sering digunakan selama ini. Selain itu, auditor merasa kinerjanya akan menjadi tidak menentu apabila ia beralih menggunakan Blockchain karena ia meyakini peralihan ini akan membawa kerepotan baginya. Keterbatasan informasi terkait potensi manfaat atau ketidakterbiasaan dalam mengoperasikan suatu sistem atau teknologi baru mengakibatkan keengganan untuk menggunakannya. Hasil penelitian H.-W. Kim (2011) dan Hsieh (2016) menemukan pengaruh Ketidakpastian terhadap resistensi penggunaan. Resistensi penggunaan merupakan reaksi negatif pengguna terhadap perubahan yang diusulkan dalam implementasi teknologi. Resistensi penggunaan berkorelasi negatif terhadap niat penggunaan (Hsieh \& Lin, 2018). Apabila transisi ke sistem baru dapat menimbulkan permasalahan tak terduga yang menyebabkan kewalahan atau kerepotan bagi individu, maka individu cenderung resisten terhadap penggunaan sistem tersebut ( $\mathrm{Li}$ et al., 2016).

Penghindaran Kerugian $(B=-0,049 ;$ Sig. $=0,557)$ tidak berpengaruh terhadap Niat Penggunaan Blockchain, jadi $\mathrm{H}_{6}$ ditolak. Biaya waktu, biaya moneter dan biaya usaha merupakan hal-hal yang harus dikorbankan untuk mendapatkan sistem atau teknologi baru, seperti lamanya waktu yang diperlukan untuk mempelajari teknologi baru, besaran biaya yang diperlukan untuk mempelajari teknologi dan usaha yang dibutuhkan untuk bisa mahir menggunakan sistem atau teknologi baru. Semakin besar perbedaan antara teknologi audit yang digunakan saat ini dan Blockchain, maka auditor akan cenderung enggan menggunakan Blockhain. Juga karena potensi kerugian dari penggantian teknologi yang ada saat ini dianggap lebih besar daripada potensi manfaat yang diperoleh dari penggunaan Blockchain. Penghindaran Kerugian berpengaruh positif terhadap resistensi penggunaan (Hsieh, Lai, \& Hong, 2015), artinya semakin tinggi inersia, maka semakin tinggi pula resistensi penggunaan teknologi, sebaliknya inersia mengakibatkan rendahnya niat penggunaan teknologi (Hsieh et al., 2015). Inersia merupakan keterikatan atau ketergantungan individu terhadap sistem atau teknologi yang selalu digunakan walaupun ada sistem alternatif yang lebih baik atau ada insentif bagi yang menggunakan sistem alternatif (Rey-Moreno \& Medina-Molina, 2017). Inersia juga memediasi efek penghindaran kerugian terhadap niat penggunaan teknologi yang mengakibatkan rendahnya niat penggunaan teknologi (Gong, Zhang, Chen, Cheung, \& Lee, 2020).

Biaya Tertanam $(B=-0,346 ;$ Sig. $=0,002)$ berpengaruh secara negatif terhadap Niat Penggunaan Blockchain, jadi $\mathrm{H}_{7}$ diterima. Auditor merasa telah menginvestasikan waktu, biaya dan usaha untuk menjadi terampil dalam menggunakan teknologi saat ini. Semakin besar jumlah sumber daya yang telah diinvestasikan oleh individu dalam sistem yang sedang digunakan, maka semakin besar kemungkinannya untuk terus berkomitmen pada sistem tersebut, 
sehingga cenderung tidak ada perubahan dalam situasi mereka (Zhang, Guo, Wu, Lai, \& Vogel, 2017). Temuan ini didukung oleh hasil penelitian Rey-Moreno \& Medina-Molina (2017) mengkonfirmasi variabel biaya tertanam sebagai faktor penghambat dalam pengadopsian sistem atau teknologi baru. Biaya Tertanam juga memengaruhi niat penggunaan dengan dimediasi oleh persepsi manfaat, artinya Biaya Tertanam berpengaruh secara negatif terhadap persepsi manfaat yang kemudian melemahkan niat penggunaan (Zhang et al., 2017).

Penghindaran Penyesalan $(B=-0,169 ;$ Sig. $=0,158)$ tidak berpengaruh terhadap Niat Penggunaan Blockchain, jadi $\mathrm{H}_{8}$ ditolak. Auditor merasa sudah nyaman menggunakan teknologi audit yang ada saat ini dan akan menyesal apabila beralih menggunakan Blockhain. Penghindaran penyesalan didasarkan pada alasan orang takut membuat keputusan yang mereka anggap mungkin berisiko memicu situasi baru yang dapat membuat mereka menyesal dan hal ini cenderung terjadi apabila individu yang mengambil inisiatif sendiri (ReyMoreno \& Medina-Molina, 2017). Karena teknologi Blockchain merupakan teknologi yang baru dan belum pernah dioperasikan oleh auditor, maka beralih menggunakan Blockchain dipandang dapat menimbulkan situasi baru yang berpotensi membuat mereka menyesali keputusan mengganti teknologi audit yang digunakan sebelumnya. Hasil penelitian ini tidak menemukan adanya pengaruh langsung dari Penghindaran penyesalan terhadap niat penggunaan, namun Penghindaran penyesalan memiliki pengaruh secara langsung dan positif terhadap resistensi penggunaan; dan resistensi penggunaan berkorelasi negatif dengan niat penggunaan (Hsieh et al., 2015) dan (Hsieh \& Lin, 2018).

\section{SIMPULAN}

Dari hasil analisis data dan pembahasan, disimpulkan bahwa terdapat tiga variabel yang berpengaruh terhadap Niat Penggunaan Blockchain, yaitu Ekspektasi Usaha, Faktor Sosial Budaya dan Biaya Tertanam. Ekspektasi Usaha dan Faktor Sosial Budaya mendukung niat penggunaan Blockchain oleh auditor yang bekerja di KAP di Bali. Artinya semakin tinggi tingkat ekspektasi usaha auditor atas teknologi Blockchain, maka semakin tinggi pula niat penggunaannya; dan bila lingkungan sosial auditor, pandangan pribadinya dan tingkat spiritualitasnya dapat menerima pengadopsian Blockchain, maka akan meningkatkan niat penggunaanya. Sementara Biaya Tertanam menghambat niat penggunaan Blockchain oleh auditor. Artinya, apabila auditor merasa telah menginvestasikan biaya, waktu dan usahanya dalam menggunakan suatu sistem atau teknologi dan sudah terbiasa dalam penggunaannya, maka auditor semakin enggan untuk beralih menggunakan teknologi baru, seperti Blockchain, meskipun teknologi alternatif memiliki manfaat lebih baik daripada teknologi yang digunakan saat ini.

Penelitian ini menggunakan variabel-variabel yang ditentukan berdasarkan penelitian-penelitian terdahulu. Namun tidak menutup kemungkinan adanya variabel-variabel lain yang dapat mempengaruhi niat penggunaan teknologi oleh auditor, baik yang bersifat mendukung maupun menghambat pengadopsiannya. Oleh sebab itu, penelitian selanjutnya sebaiknya menambahkan variabel-variabel lain yang dianggap berpotensi mempengaruhi niat penggunaan teknologi, seperti umur, pendidikan dan pendapatan, untuk 
dapat menjelaskan niat penggunaan teknologi secara lebih lengkap terkait efek moderasi maupun mediasinya. Juga disarankan bagi peneliti selanjutnya untuk memberikan strategi yang dapat digunakan sebagai langkah antisipatif atas perubahan-perubahan yang mungkin terjadi terkait dengan implementasi teknologi baru dalam organisasi.

\section{REFERENSI}

Abreu, P. W., Aparicio, M., \& Costa, C. J. (2018). Blockchain technology in the auditing environment. In Proceedings of the 13th Iberian Conference on Information Systems and Technologies (CISTI) (pp. 1-6). Caceres, Spain: IEEE. https:// doi.org/10.23919/CISTI.2018.8399460

Alles, M. G. (2015). Drivers of the Use and Facilitators and Obstacles of the Evolution of Big Data by the Audit Profession. Accounting Horizons, 29(2), 439-449. https:/ / doi.org/10.2308/acch-51067

Appelbaum, D., \& Nehmer, R. A. (2017). Designing and Auditing Accounting Systems Based on Blockchain and Distributed Ledger Principles. In 40th World Continuous Auditing and Reporting Symposium (pp. 1-19). Newark, NJ, USA: Rutgers University.

Ariyanto, D., Sari, M. M. R., \& Ratnadi, N. M. D. (2017). Budaya Tri Hita Karana dalam Model UTAUT. Jurnal Akuntansi Multiparadigma, 8(2), 399-415. https:// doi.org/10.18202/jamal.2017.08.7062

Bierstaker, J., Janvrin, D., \& Lowe, D. J. (2014). What Factors Influence Auditors' Use of Computer-Assisted Audit Techniques? Advances in Accounting, 30(1), 67-74. https:// doi.org/10.1016/j.adiac.2013.12.005

Chedrawi, C., \& Howayeck, P. (2018). Audit in the Blockchain era within a principal-agent approach. In Information and Communication Technologies in Organizations and Society. Paris, France: University Paris Nanterre - Pole Léonard de Vinci.

Chung, M., \& Kim, J. (2016). The Internet Information and Technology Research Directions based on the Fourth Industrial Revolution. KSII Transactions on Internet and Information Systems, 10(3), 1311-1320. https:// doi.org/10.3837/ tiis.2016.03.020

Dian Saputra, I. W., \& Dwirandra, A. A. N. B. (2015). Analisis Faktor-Faktor yang Mempengaruhi Minat Pemanfaatan Teknik Audit Sekitar Komputer. EJurnal Akuntansi, 12(2), 395-409.

Direktori Kantor Akuntan Publik dan Akuntan Publik 2019. (2019). Retrieved January 31, 2019, from http://iapi-lib.com/directory-2019/

Gong, X., Zhang, K. Z. K., Chen, C., Cheung, C. M. K., \& Lee, M. K. O. (2020). Transition from web to mobile payment services: The triple effects of status quo inertia. International Journal of Information Management, 50, 310-324. https:/ / doi.org/10.1016/J.IJINFOMGT.2019.08.006

Heryangi, H., \& Ariyanto, D. (2018). Faktor-Faktor yang Mempengaruhi Minat Pemanfaatan dan Penggunaan Sistem Online Travel Agent di Industri Perhotelan. E-Jurnal Akuntansi, 23(1), 626-650. https:// doi.org/10.24843/EJA.2018.v23.i01.p24

Hsieh, P.-J. (2016). An empirical investigation of patients' acceptance and resistance toward the health cloud: The dual factor perspective. Computers in 
Human Behavior, 63, 959-969. https://doi.org/10.1016/J.CHB.2016.06.029

Hsieh, P.-J., Lai, H.-M., \& Hong, Y.-L. (2015). Explaining Physicians' Acceptance and Resistance to the NHI Pharmacloud: A Theoretical Model and Empirical Test. In A. Kankanhalli, A. Burton-Jones, \& T. S. H. Teo (Eds.), Proceedings of the 19th Pacific Asia Conference on Information Systems (PACIS) (pp. 247-261). Singapore: Association for Information Systems.

Hsieh, P.-J., \& Lin, W.-S. (2018). Explaining resistance to system usage in the PharmaCloud: A view of the dual-factor model. Information $\mathcal{E}$ Management, 55(1), 51-63. https://doi.org/10.1016/J.IM.2017.03.008

Jayanti, P. E., \& Ariyanto, D. (2018). Pengaruh Ekspektansi Kinerja, Ekspektansi Usaha, Faktor Sosial Budaya dan Kondisi yang Memfasilitasi pada Penerapan SIA di LPD Kota Denpasar. E-Jurnal Akuntansi, 27(1), 534-567. https:// doi.org/10.24843/EJA.2019.v27.i01.p20

Kim, H.-W. (2011). The Effects of Switching Costs on User Resistance to Enterprise Systems Implementation. IEEE Transactions on Engineering Management, 58(3), 471-482. https://doi.org/10.1109/TEM.2010.2089630

Komala Dewi, N. K. L. R., \& Yadnyana, I. K. (2017). Faktor-Faktor Yang Mempengaruhi Minat dan Perilaku Penggunaan Sistem E-Filing Di Kota Denpasar dengan Model UTAUT. E-Jurnal Akuntansi, 21(3), 2338-2366. https:// doi.org/10.24843/eja.2017.v21.i03.p23

Koens, T., \& Poll, E. (2019). The Drivers Behind Blockchain Adoption: The Rationality of Irrational Choices. In Euro-Par 2018: Parallel Processing Workshops (pp. 535-546). Italy: Springer https://doi.org/10.1007/978-3030-10549-5_42

Lafraxo, Y., Hadri, F., Amhal, H., \& Rossafi, A. (2018). The Effect of Trust, Perceived Risk and Security on the Adoption of Mobile Banking in Morocco. In S. Hammoudi, M. Smialek, O. Camp, \& J. Filipe (Eds.), Proceedings of the 20th International Conference on Enterprise Information Systems (pp. 497-502). Madeira, Portugal: SCITEPRESS - Science and Technology Publications. https:/ / doi.org/10.5220/0006675604970502

Lee, K., \& Joshi, K. (2016). Examining the use of status quo bias perspective in IS research: need for re-conceptualizing and incorporating biases. Information Systems Journal, 27(6), 733-752. https:// doi.org/10.1111/isj.12118

Li, J., Liu, M., \& Liu, X. (2016). Why do employees resist knowledge management systems? An empirical study from the status quo bias and inertia perspectives. Computers in Human Behavior, 65, 189-200. https:// doi.org/10.1016/J.CHB.2016.08.028

Mardiana, S., Tjakraatmadja, J. H., \& Aprianingsih, A. (2018). How Organizational Culture Affects Information System Success: The Case of an Indonesia IT-Based Company. Journal of Information Systems Engineering and Business Intelligence, 4(2), 84-95. https://doi.org/10.20473/jisebi.4.2.84-95

Mosunmola, A., Mayowa, A., Okuboyejo, S., \& Adeniji, C. (2018). Adoption and use of mobile learning in higher education: the UTAUT model. In Proceedings of the 9th International Conference on E-Education, E-Business, EManagement and E-Learning - IC4E '18 (pp. 20-25). San Diego, CA, USA: ACM Press. https://doi.org/10.1145/3183586.3183595

Ngafifi, M. (2014). Kemajuan Teknologi dan Pola Hidup Manusia dalam 
Perspektif Sosial Budaya. Jurnal Pembangunan Pendidikan: Fondasi Dan Aplikasi, 2(1), 33-47. https:/ / doi.org/10.21831/JPPFA.V2I1.2616

Psaila, S. (2017). Blockchain: A game changer for audit processes? Retrieved January 11, 2019, from https://www2.deloitte.com/mt/en/pages/ audit/articles/mt-blockchain-a-game-changer-for-audit.html

Rey-Moreno, M., \& Medina-Molina, C. (2017). Inhibitors of e-Government adoption: Determinants of habit and adoption intentions. Journal of Innovation $\mathcal{E} \quad K n o w l e d g e, \quad 2(3), \quad 172-180 . \quad$ https://doi.org/10.1016/ J.JIK.2017.01.001

Risma Dwinda Putri, N. K., \& Suardikha, I. M. S. (2020). Penerapan Model UTAUT 2 Untuk Menjelaskan Niat Dan Perilaku Penggunaan E-Money di Kota Denpasar. E-Jurnal Akuntansi, 30(2), 540. https://doi.org/10.24843/ EJA.2020.v30.i02.p20

Samuelson, W., \& Zeckhauser, R. (1988). Status quo bias in decision making. Journal of Risk and Uncertainty, 1(1), 7-59. https://doi.org/10.1007/ BF00055564

Schwab, K. (2016). The Fourth Industrial Revolution: what it means and how to respond. Retrieved January 7, 2019, from https://www.weforum.org/ agenda/2016/01/ the-fourth-industrial-revolution-what-it-means-and-howto-respond

Sedana, I. G. N., \& Wijaya, S. W. (2012). Penerapan Model UTAUT Untuk Memahami Penerimaan dan Penggunaan Learning Management System Studi Kasus: Experential E-Learning of Sanata Dharma University. Jurnal Sistem Informasi, 5(2), 114-120. https://doi.org/10.21609/jsi.v5i2.271

Suhendro, S., Siregar, S. V. N. P., \& Nauli, P. (2015). Resistensi Pengguna Terhadap Implementasi Sistem Informasi Akuntansi Berbasis Akrual pada Pemerintah Daerah. In Simposium Nasional Akuntansi 18. Medan: Universitas Sumatera Utara (USU).

Veerankutty, F., Ramayah, T., \& Ali, N. A. (2018). Information Technology Governance on Audit Technology Performance among Malaysian Public Sector Auditors. Social Sciences, 7(8), 124. https://doi.org/10.3390/ socsci7080124

Venkatesh, V., Morris, M. G., Davis, G. B., \& Davis, F. D. (2003). User Acceptance of Information Technology: Toward a Unified View. MIS Quarterly, 27(3), 425-478. https:/ / doi.org/10.2307/30036540

Yoo, S. J., Han, S., \& Huang, W. (2012). The Roles of Intrinsic Motivators and Extrinsic Motivators in Promoting e-Learning in the Workplace: A Case from South Korea. Computers in Human Behavior, 28(3), 942-950. https:// doi.org/10.1016/j.chb.2011.12.015

Zhang, X., Guo, X., Wu, Y., Lai, K., \& Vogel, D. (2017). Exploring the inhibitors of online health service use intention: A status quo bias perspective. Information $\mathcal{E}$ Management, 54(8), 987-997. https://doi.org/10.1016/J.IM.2017.02.001

Zuiderwijk, A., Janssen, M., \& Dwivedi, Y. K. (2015). Acceptance and use predictors of open data technologies: Drawing upon the unified theory of acceptance and use of technology. Government Information Quarterly, 32(4), 429-440. https:/ / doi.org/10.1016/J.GIQ.2015.09.005 